\title{
Regular COVID-19 Pandemic Containment in Communities: A Risk Governance Perspective
}

\author{
Huijie Li \\ Liwei Zhang \\ Long Wang \\ Tianjiao Xu iD \\ School of Public Administration, Jilin \\ University, Changchun, People's Republic \\ of China
}

\begin{abstract}
Post COVID-19, differentiated regular management in place of strict lockdowns is more favored as a feasible option for balancing economic resumption and pandemic control. China's transition experience shows that this stage came not easily, during which regional sporadic outbreaks could re-emerge. Actually, it is an ongoing process of identifying loopholes and refining the management. Based on the IRGC risk governance framework, this article analyzes these challenges in community involvement posed by the transition. The systematic examination of the whole risk chain would be conducive to contain the virus spread, lessen the pressure of communities for the battle and enhance future responses for a possible resurgence. Unlike the emergency mode with mass mobilized, during regular control periods, community becomes the critical frontline for suppressing COVID-19 but with limited manpower and resources. Still, it can serve as a transformation platform to motivate atomized residents to take responsibility or contribute. Notably, the health governance of all people never ends. With the increased knowledge of COVID-19, the progress of pandemic control, and the needed adjustments for behavioral responses, different communities should come up with more suitable options instead of rigid management back to the old days.
\end{abstract}

Keywords: pandemic control experience, IRGC risk governance framework, China, COVID-19

\section{Introduction}

Till June 10 of 2021, the WHO reported that there have been 174,061,995 confirmed cases of COVID-19, including over 3.7 million deaths. Globally, there are still 43 countries experiencing clusters of cases, while 150 other countries are having community transmissions. ${ }^{1}$

The pandemic put extremely high pressure on most countries' health systems, in which doctors and healthcare workers were firstly affected shouldering the heavy workloads with resource constraints and exposure risk of the virus. Their physical status, mental health and satisfaction of jobs and lives are being severely trampled. $^{2-6}$

Not only the healthcare sector is hit, the pandemic and countries' responses affected many sectors dramatically. In today's interconnected world, local, national and global supply chains are disrupted, which brings almost all sectors uncertainties. $^{7}$ The everyday life of citizens has to face the challenges posed by the COVID-19 as well: remote work, online classes and other lives moved to the internet adapting to the preventive measures. Economic stress, decreased social interaction and anxiety caused by the spread of fake news, etc., may also lead to
Correspondence: Tianjiao Xu Jilin University, Changchun, People's Republic of China

Tel +86 I5764324495

Email xtjjlu0I@I63.com 
psychological problems. ${ }^{8,9}$ Notably, India's recent resurgence of coronavirus is dragging the whole world into a more unclear future attributed to uncertainties of virus variants.

As the COVID-19 pandemic continues, living with the virus will last for a certain period of time. On the one hand, life cannot return to the old days before the vaccine provides good protection against the pandemic, which requires suppressing efforts from both the government and citizens. On the other hand, even when the drastic increase in the number of Corona infections is likely to overload the health system, strict rules such as "lockdown" and night-time curfew imposed by the government may face significant resistance from citizens, without which effective containment is impossible. In this way, regular control measures instead of response in emergency mode are more favored, and targeted suppression response with to the best closing management loopholes is therefore recommended. Under this circumstance, communities become the main battle field and the critical frontline for suppressing COVID-19. Considering China's successful transition to the regular control phase, this article analyzes the challenges in community involvement posed by the transition from the emergency mode, based on the IRGC (International Risk Governance Council) risk governance framework. Even for China, the current "normal" containment routine did not come easily. After around one year's repetitive transition between emergency mode and regular control mode, it seems that targeted suppression measures worked. China's experiences may be of help to countries in the tough fight against COVID-19 as confirmed cases resurge. The war between humans and the virus will not come to a halt as long as COVID-19 cases spiral globally. For the moment, vigilance is still needed.

\section{Analysis from the Risk Governance Perspective}

Globally, responses to COVID-19 have been created by different national governments, the variation of which evolves with conditions of the disease spread, governments' interventions, and citizens' reactions. ${ }^{10}$ To enhance responses to the pandemic, medical professionals, policymakers, and the public play respective but indispensably important roles in the whole process. The risk governance framework, developed by the IRGC, integrating assessment and management, can be used as a tool for policymakers and others to shape effective risk responses. It provides an interdisciplinary approach and an analytical structure to identify, assess, handle, and communicate risks in a broad context. It proposes how to integrate effective involvement of stakeholders and come up with management strategies, to help understand a risk and decide what to do about it for which deficits can exist in risk governance structures and processes. ${ }^{11}$ The added value of the IRGC framework was evaluated in the infectious disease control based on Dutch case studies: Unlike the classical top-down risk management approach, the application of the IRGC framework enables the inclusion of stakeholders' perception and preferences, which could enhance the effectiveness and acceptance of infectious disease governance. ${ }^{12}$ The IRGC framework was also used to analyze, assess and manage emerging health risks attributed to vector-borne diseases to help provide operational guidelines in a systematic way. ${ }^{13}$ Considering conflicting values among policymakers and the public, it was suggested that measures to contain the current pandemic should be grounded on both the scientific assessment and the perception assessment. After an overview of the COVID-19 outbreak and countries' responses to it, recommendations were drawn from the IRGC framework to increase preparedness for future crises. ${ }^{14}$ There are few other studies applying the IRGC framework into the COVID-19 prevention and control. This article adds value for the approach employed in a dynamic and continuously changing context from China's case, by discussing the distinction of risk governance in different periods.

Taking China, for example, this article shows that the regular control stage comes not once and for all, which requires fined management adjustment and deserves allround attention after the outbreak peak. Multiple sporadic community outbreaks could re-emerge in different regions (see Table 1), due to later confirmed imported passengers, asymptomatic carriers and contaminated cold-chain products, etc. If government officials loosen their nerves, COVID-19 cases could emerge again and again, no matter in urban or rural areas, no matter in bigger cities or remote small villages. The same is that during the regular control phase, communities with limited manpower, limited resources, and weak cooperation from citizens are being threatened by possible transmissions from anywhere all the time, except when the emergency mode can be initiated.

To identify vulnerabilities and outline loopholes in the Chinese combatting measures evolving with the crisis, the analysis proceeds considering the elements of the IRGC 
Table I Sporadic Community Outbreaks in Local China After the Wuhan Outbreak Peak

\begin{tabular}{|c|c|c|}
\hline Region & $\begin{array}{l}\text { Date of the First } \\
\text { Case }\end{array}$ & $\begin{array}{l}\text { Date of No New } \\
\text { Cases }\end{array}$ \\
\hline $\begin{array}{l}\text { Heilongjiang } \\
\text { Province }\end{array}$ & April 9, 2020 & April 28, 2020 \\
\hline Beijing City & April I5, 2020 & April 16, 2020 \\
\hline Jilin Province & May 8, 2020 & May 24, 2020 \\
\hline Wuhan City & May 9, 2020 & May 19, 2020 \\
\hline Beijing City & June II, 2020 & July 6, 2020 \\
\hline Xinjiang Province & July I5, 2020 & Aug 18, 2020 \\
\hline Liaoning Province & July 22, 2020 & Aug 8, 2020 \\
\hline Xinjiang Province & Oct 24, 2020 & Nov 8, 2020 \\
\hline Tianjin City & Nov 8, 2020 & Nov 2I, 2020 \\
\hline $\begin{array}{l}\text { Inner-mongolia } \\
\text { Province }\end{array}$ & Nov 2I, 2020 & Dec 10, 2020 \\
\hline Sichuan Province & Dec 7, 2020 & Dec 18, 2020 \\
\hline Beijing City & Dec I4, 2020 & Jan 30,2021 \\
\hline Liaoning Province & Dec I5, 2020 & Jan 10, 2021 \\
\hline Hebei Province & Jan 2, 202I & Feb 7, 202I \\
\hline $\begin{array}{l}\text { Heilongjiang } \\
\text { Province }\end{array}$ & Jan I0, 202I & Feb 9, 202I \\
\hline Jilin Province & Jan II, 202I & Feb 7, 202I \\
\hline
\end{tabular}

Note: The exact dates were collected by reviewing newspaper articles and crosschecked with daily reports from the National Health Commission of the People's Republic of China (Retrieved from http://www.nhc.gov.cn/xcs/yqtb/list_gzbd.shtml).

risk governance framework: pre-assessment, appraisal, evaluation, management, and communication of the risk. ${ }^{11,15,16}$ It proposes a comprehensive and adaptable set of guidelines for risk governance, which could help address community challenges raised by the COVID-19 pandemic and direct resources to be used more effectively. After the transition to regular control periods, with the challenges communities facing discussed under the framework phase by phase, a short summary is listed in Table 2 to review the change of tasks and warn the differences between the two modes. This systematic examination of the whole risk chain would be conducive to contain the virus spread, lessen the pressure of communities for the battle and enhance future responses for a possible resurgence.
Table 2 Differences of Emergency Mode and Regular Control Mode for Communities

\begin{tabular}{|c|c|c|}
\hline & Emergency Mode & $\begin{array}{l}\text { Regular Control } \\
\text { Period }\end{array}$ \\
\hline $\begin{array}{l}\text { Problem } \\
\text { framing }\end{array}$ & $\begin{array}{l}\text { Nothing else but } \\
\text { COVID-19 }\end{array}$ & $\begin{array}{l}\text { Differentiated } \\
\text { pandemic control }\end{array}$ \\
\hline $\begin{array}{l}\text { Hazard } \\
\text { identification }\end{array}$ & Stop transmission & Prevent importation \\
\hline $\begin{array}{l}\text { Exposure } \\
\text { assessment }\end{array}$ & $\begin{array}{l}\text { Multiple transmission } \\
\text { routes }\end{array}$ & $\begin{array}{l}\text { Health monitoring of } \\
\text { people coming from } \\
\text { medium- and high- } \\
\text { risk areas }\end{array}$ \\
\hline Risk evaluation & $\begin{array}{l}\text { The disease spread is } \\
\text { closer to intolerable }\end{array}$ & $\begin{array}{l}\text { The residual risk can } \\
\text { be tolerated }\end{array}$ \\
\hline $\begin{array}{l}\text { Stakeholder } \\
\text { involvement }\end{array}$ & Massive mobilization & $\begin{array}{l}\text { Community } \\
\text { committee mainly, } \\
\text { with grid } \\
\text { management }\end{array}$ \\
\hline $\begin{array}{l}\text { Individual } \\
\text { protection } \\
\text { awareness }\end{array}$ & High & Low \\
\hline $\begin{array}{l}\text { Protection } \\
\text { measures }\end{array}$ & $\begin{array}{l}\text { Avoiding movement } \\
\text { and crowds, optimizing } \\
\text { the way to purchase } \\
\text { and/or distribute food } \\
\text { supply and other } \\
\text { materials }\end{array}$ & $\begin{array}{l}\text { Voluntary self- } \\
\text { protection; } \\
\text { vaccination coverage }\end{array}$ \\
\hline Communication & $\begin{array}{l}\text { In-time } \\
\text { communication about } \\
\text { the uncertainty; the } \\
\text { importance of wearing } \\
\text { masks and other self- } \\
\text { protection measures; } \\
\text { the importance of } \\
\text { avoiding movement } \\
\text { and crowds; rumor } \\
\text { refuting in case of } \\
\text { secondary risks }\end{array}$ & $\begin{array}{l}\text { Immunity } \\
\text { enhancement advice; } \\
\text { updated epidemic } \\
\text { status and } \\
\text { management } \\
\text { measures; Q\&A } \\
\text { about vaccination; } \\
\text { self-protection } \\
\text { reminder during } \\
\text { holidays }\end{array}$ \\
\hline
\end{tabular}

Note: The content of this table is summarized based on the analysis using the IRGC framework.

\section{Pre-Assessment}

Risk pre-assessment captures the various dimensions of the risk and associated opportunities to address it, the framing of which forms the baseline for how the risk will be assessed and handled. ${ }^{11}$ For the emergency mode in China, COVID-19 pandemic control has been given top priority. At the very beginning, President Xi Jinping 
declared a "people's war" and "war-time mode" can be seen quite often in the official media reports in later local fights. Therefore, full support from all-levels of government as many means as available and mass mobilized together with resources from other regions and abroad contribute to the "war-time speed".

After the outbreak peak has passed, most provinciallevel regions lowered their emergency response levels. The national government announced that differentiated and county-specific measures for COVID-19 control should be adopted by local governments at different risk levels. ${ }^{17}$ Since May 7 of 2020, the regular control stage came and community-level response tactics have become the main body of the pandemic prevention. ${ }^{18}$ Besides, public health alert system should be in place to declare risk areas in time, with multi-channel surveillance among key populations and the environment to ensure early identification. $^{19}$

During regular control periods, the pandemic control is no more "everything" of the day for communities, but a large amount of workload for other tasks is normally confronted by community committees in the meantime. The framing that conceptualizes the issue changes (shown in Table 2), which will determine the regulatory path (focus transited from stopping inner transmission to preventing virus importation) and influence how the chosen management strategy will be implemented. ${ }^{20}$ Although without extra assistance from industries and temporary volunteer teams for entrance control, quarantine measures, material support, and sanitization work, it requires communities themselves high vigilant of potential infection risks. In re-opened communities, flowed population made it hardly possible for overall health surveillance unless returnees report their travel histories voluntarily. To address this screening problem, some communities insert digital machines for temperature checks at the entrance. In addition, with border control and central isolation of imported passengers from other departments, communities could focus on following-up the returnees from high-risk areas. Early recognition (e.g., regular COVID-19 testing among key population) to prevent further transmission is the most important tactic of communities at this phase. To transit to the normal work mode, environment sanitization cutting off disease transmission route is gradually integrated into routine work of health campaigns according to the Healthy China 2030 strategy.

\section{Risk Appraisal}

Risk appraisal combines the scientific risk assessment (of the hazard, its probability and possible consequences) and the concern assessment (concerns and perceptions of stakeholder groups), these together shaping governmental interventions and individual protective behaviors. ${ }^{11}$ Although there are still scientific uncertainties about COVID-19 variants, management strategies could be shaped according to the discoveries of the significant level of asymptomatic transmission of the coronavirus, human-to-human transmission, and the incubation period. $^{21}$ In particular, the Xinfadi Market outbreak in Beijing in June 2020 adds evidence that cold-chain imports are likely to be a transmission risk, which leads to the virus survival period and transmission distance prolonged. $^{22}$ Aware of the potential consequences, China ramped up checks on cold-chain imports. After China has almost eradicated local transmission of coronavirus, the focus is then turned to prevent importation (see Table 2), which could initiate a new outbreak.

As the entire population is susceptible to COVID-19 infection with its transmissibility characteristics, everyone has been repetitively told to wear masks to protect each other. If confirmed cases were found too late, it is far more difficult to trace the origin of the infections, and then short but strict lockdown together with mass virus tests become necessary. China's initial success enables lockdown strategies to exit to some extent, as long as imported passengers from medium- and high-risk areas are well managed. Once a new cluster emerges, emergency mode will be initiated, and strict measures will be taken so that the transmission to wider communities could be stopped in time. Even if older adults are at a higher risk of mortality and severe disease after being infected, even if some of their social activities in groups could facilitate the spread, they are now in good protection away from the virus. Also, they do not need vaccinations in a hurry until clinical test results are encouraging, and the health condition of individual elderly is sufficiently evaluated. ${ }^{23}$ In this phase, local governments should take measures according to their own situations, as they differ in epidemic status, distribution of risky zones (e.g., border area), and capacities in various kinds of support. The "One-size-fits-all" approach will not work and should not be only keen to enhance the limit in population mobility. During the Spring Festival holiday, local authorities had been requested that scientific 
and targeted measures but not overly strict travel ban should be adopted.

\section{Risk Evaluation}

Risk evaluation is the prior basis before the careful decision of politicians, evaluating whether the risk is acceptable without any interventions, or tolerable if appropriate risk reduction measures are taken, or intolerable no matter what precautions are taken. ${ }^{11}$ Unlike many other countries tolerating the COVID-19 risk by imposing risk reduction measures, China appears to treat the disease spread almost intolerable with more stringent and comprehensive tactics to suppress the outbreak. ${ }^{14}$ Although citizens could not reach a consensus about the evaluation, legally enforced measures supplement voluntary protective behaviors. When it comes to the regular control period, most people treat the residual risk as tolerable with voluntary selfprotection strategies and strict oversight measures from the government (see Table 2).

For community engagement and residents involved in the regular control, double tasks which are work revitalization and pandemic control need to be balanced. Instead of lockdown and restricted travel all the time, containing the risk in a dynamic way is more tolerable. Instead of locking down all regions, targeted closure and differentiated management according to the corresponding risk levels are more tolerable.

\section{Risk Management}

After judging by the decision-makers whether a risk is acceptable or not, risk management involves reduction measures to be taken to make it more tolerable. It includes designing, selecting, and implementing options to reduce the adverse consequences associated with the risk. ${ }^{11}$ Unlike other countries, the uncertainty of the transmission risk is much lower for China after the Wuhan outbreak. Besides, there are few divergent views about why it is important and how to deal with the COVID-19, citizens tend to comply as the strict control measures are normally in short term but quite effective in a campaign style. For China's case, it is notable that the transition to a regular control period means the goal setting from the bottom line of medical-care resources shifting to prevention as a population health strategy. Regular control measures are based on the community grid management, trying to isolate the COVID-19 far away at the monitoring source with the cooperation of all other work units necessary. Different from mass mobilization in the emergency mode, community tasks turn to follow-up procedures for key population, awareness promotion and vaccine education with limited manpower and resources.

The fight against COVID-19 is not only a virus containment problem but health governance of all people. One recipe of China's success in combating the COVID-19 lies in the emergency management relying on citizens, which is called "mass prevention and defense", which involved crowds and movement avoidance, health screening, material supplies, sanitization, and information distribution. ${ }^{24}$ Therefore, communities as the frontline of the COVID-19 battle represent the most effective defense or the most vulnerable transmission hubs. In addition to fast testing and laborious epidemiological investigation locking down the high-risk areas, most other areas remain unaffected under the grid management enabling rapid responses to the resurgence (see brief comparison in Table 2). This matrix of urban or rural communities divided into unit grids integrating management objects, responsibility, and resource allocation, has been the key to China's achievement in fighting against COVID-19. ${ }^{25}$ As it provides a participation platform for multiple stakeholders such as residents, self-organizations, social organizations, and other formal or informal service organizations, kinds of contributions may lead to improved community governance transforming atomized individuals to community solidarity with shared understanding. Some regions even created online grid management to provide fast information and convenient service without contact complementing offline mode.

\section{Risk Communication}

Risk communication is the process of sharing risk-related information within and between different stakeholder groups such as policymakers, scientists, and the general public. ${ }^{11}$ The ambiguity resulting from divergent views about the priority and needed reactions of dealing with the COVID19 makes effective risk communication more important than ever. China's case succeeded in the good cooperation between experts and policymakers, and also the critical bridge - community committees - between the public and the government. Medical experts transmit knowledge and emphasize the importance of personal protection and each one as a fighter against the virus in a vivid way. Community workers closest to citizens disseminate risk-related information and updated epidemic status around the area. To ensure messages received for the last kilometer, various channels have been used such as printed brochures, broadcasting 
stations or vehicles, online grid communication channels or WeChat groups. In some places, there are special psychological assistance hotlines, for online entertainment there are TV programs and WeChat groups to enrich the social life of residents. Service and information updating become much faster and more convenient, after committee teams built the communication channel with everyone serving everyone. As shown in Table 2, in the emergency mode, community workers tell residents the importance and way of selfprotection repetitively both online and offline to cover different groups. Rumor refuting in time together with suitable punishment for the rumor mongers could block the development of secondary effects. With progress in epidemic control efforts and increased understanding of COVID-19, health education strategies need to be updated, vaccination facilitation, for example. At regular control periods, updated epidemic status is still needed to be daily presented and communicated, as citizens' protection awareness and willingness to take vaccine shots seem to rise after resurgence of cases.

\section{Conclusion and Discussion}

It was found that the communities play a critical role in the success of China's experience in combating the COVID$19 .^{26}$ Still, during the regular control periods, communities matter most to the quality of revitalized life when it became the frontline of the flowed world protecting the residents from virus importation. Taking the IRGC framework to review the efforts of communities in the regular COVID19 prevention, the core results of analyses are shown in Table 3 in different phases, which explores the feasibility of the framework applied in the disease control and indicates the importance of communities again. No matter at which phase, community workers need to be there with residents providing information and protective advice, and other services such as sanitization, healthcare consultation and vaccination plan. Also, preventing the resurgence requires the cooperation from returnees or travelers, experts, volunteers, etc., in different phases. One important experience to control the pandemic cost-effectively from China is the screening and blocking strategy, particularly regular check on key population (such as people work at hospitals, airports, and customs), enables early recognition and blocks the virus outside communities as early as possible. Before the population immunity is good enough, these non-medical measures are still necessary. In sum, the sets of regular management measures did not come once and for all. They are gradually formed and updated with the increasing knowledge of COVID-19, the progress of epidemic control and needed changes for behavioral responses and prevention measures after each sporadic outbreak shown in Table 1. Another notable progress is that privacy issues are treated with more caution and being better protected after rounds of information disclosure. People become less anxious and more reasoned towards the virus but not emotional against victims who carry the virus. Yet, as long as the pandemic continues, we should keep vigilant for a long while: on March 29 of 2021, the cases resurge in Ruili City in Yunnan Province of China after one positive COVID-19 case was confirmed. On one hand, it means certain management loopholes exist in the border control; on the other hand, regular COVID-19 testing among high-risk groups enabled

Table 3 Regular Control Efforts from Communities

\begin{tabular}{|l|l|l|l|}
\hline & Controlling Source & Cutting the Transmission Route & Protection Measures \\
\hline Pre-assessment & $\begin{array}{l}\text { Targeted management of at-risk population, } \\
\text { including returnees from high-risk areas }\end{array}$ & Environment sanitization & Early recognition \\
\hline Risk appraisal & $\begin{array}{l}\text { Health monitoring of people coming from } \\
\text { high-risk areas }\end{array}$ & $\begin{array}{l}\text { Design differentiated county-specific } \\
\text { measures }\end{array}$ & $\begin{array}{l}\text { Health preventive measures for } \\
\text { different groups }\end{array}$ \\
\hline Risk evaluation & Tolerable & Tolerable & Tolerable \\
\hline $\begin{array}{l}\text { Risk } \\
\text { management }\end{array}$ & $\begin{array}{l}\text { Early identification by regular testing of key } \\
\text { population }\end{array}$ & $\begin{array}{l}\text { Short and strict lockdown of high-risk } \\
\text { areas leaving other areas unaffected }\end{array}$ & $\begin{array}{l}\text { In combination with normal health } \\
\text { service for vulnerable groups }\end{array}$ \\
\hline $\begin{array}{l}\text { Risk } \\
\text { communication }\end{array}$ & $\begin{array}{l}\text { Health monitoring advice with updated } \\
\text { epidemic status }\end{array}$ & $\begin{array}{l}\text { Travel advice; healthcare guidelines for } \\
\text { suspected patients }\end{array}$ & $\begin{array}{l}\text { Immunity enhancement; self- } \\
\text { protection reminders }\end{array}$ \\
\hline
\end{tabular}

Note: The content of this table is summarized based on the analysis using the IRGC framework. 
early identification, which emphasizes the high importance of efforts of local communities. In addition, COVID-19 mutations bring more challenges to pandemic control besides India. Recent outbreak in Guangzhou reveals the variant with a higher viral load and more transmissible than before. ${ }^{27}$ Learning from India's failures in controlling the COVID-19, the most noteworthy one is declaring "endgame" of the pandemic too early. The Indian government ignored the repeated warnings of dangers and underestimated the continuity and uncertainty of the pandemic. And they missed the golden time preparing for future waves. ${ }^{28}$ Willing to identify the barriers and facilitators for implementation of preventive measures such as avoiding assembly and vaccination campaigns, is critical to prevent the transmission in communities. Removing criticism on Twitter does not help. ${ }^{29,30}$

In China, communities as the closest link to residents in the governance chain have been faced with challenges from loosened management possibilities in quarantine for people from high-risk areas, declined awareness of self-protection, increased difficulty of health monitoring in an open environment and so on. Luckily, most regions are at low risk-levels within China, and there is assistance from technology such as mass temperature checks at entrances, green health code to ensure free mobility, and fast testing to target the suspected cases. However, the health governance of all people never ends. Any link of the governance chain slackened (see Table 4); then, the COVID-19 cases may resurge, unless the vaccination speed and coverage go up substantially.
Unfortunately, China's rollout of vaccine shots is proceeding quite slowly, covering about $4 \%$ of the whole population till April 2, 2021. ${ }^{31}$ The slow speed of vaccination in some regions of China may reflect the slackness after domestic life seems to turn back to normal. Many older adults and others have doubts about the side effects and the children protection, particularly when the threat seems quite far away. ${ }^{32}$ After the recent resurgence of cases, more people tend to receive vaccine shots. Nearly 825 million vaccine shots were given till June 9, with daily 20 million shots at the peak. ${ }^{33}$ The speed-up cannot leave the efforts of communities, which provide full services from publicity, registration, volunteer organization to vaccine administration together with community health centers.

Learning from the experiences, communities matter as they publicize the information closest to citizens, as it could motivate people to fight together as a whole, not only because it is important COVID-19 battlefield to suppress local transmission. Transiting from the emergency mode to the regular control stage, vigilance is now being weakened. Integrating the suppressing measures into the normal government rather than emergency response periodically did not attract enough attention. Even though the Chinese government is trying to integrate the epidemic control work into population health strategy by upgrading the health functions of grid management, further immediate efforts to consolidate the COVID-19 success seem to fall behind at the community level. Vaccination as prevention seems much easier compared with other control measures did not raise

Table 4 Management Loopholes Identified from the Sporadic Outbreaks in Communities

\begin{tabular}{|l|l|l|l|}
\hline \multicolumn{2}{|l|}{ Phase } & Management Loopholes & Example \\
\hline Pre-assessment & Screening & $\begin{array}{l}\text { Slackened management for the pre-admission COVID-19 tests in } \\
\text { hospital }\end{array}$ & Heilongjiang \\
\hline \multirow{2}{*}{ Appraisal } & Hazard analysis & Emerging risk from cold-chain imports & $\begin{array}{l}\text { Beijing, Tianjin, } \\
\text { Liaoning }\end{array}$ \\
\cline { 2 - 5 } & Risk perception & Hospital staff lacking in protection awareness & Heilongjiang \\
\cline { 2 - 5 } & & Low awareness of self-protection & Hebei, jilin \\
\hline \multirow{2}{*}{ Evaluation } & $\begin{array}{l}\text { Factors influencing } \\
\text { Management }\end{array}$ & Holiday celebrations in groups including family reunion activities & Jilin, Hebei \\
\cline { 2 - 5 } & Standard & Delayed adjustment in isolation measures & Heilongjiang \\
\hline \multirow{2}{*}{ Communication } & Privacy protection & Slackened management in home quarantine & Liaoning, jilin \\
\hline
\end{tabular}

Note: The content of this table is summarized based on the analysis using the IRGC framework. 
adequate concern from the population. Some communities equate regular control with management back to the old days and did not adapt their minds yet to the population health phase. The contents of public education were not updated timely. Are they waiting for the next resurgence like Guangzhou or India so that citizens tend to be more willing to have vaccine shots as COVID-19 goes back to higher priority? In that way, the costs may be too high.

\section{Abbreviation}

IRGC, International Risk Governance Council.

\section{Funding}

This work was supported by the National Social Science Fund for Young Scholars (grant number 18CZZ010); the Integrity Research Program at Jilin University (grant number 2017LZY016); and the Seed Funding of Basic Research Operating Expense of Jilin University (grant number 2021ZZ012).

\section{Disclosure}

The authors report no conflicts of interest in this work.

\section{References}

1. World Health Organization. WHO COVID-19 dashboard. Available from: https://covid19.who.int. Accessed June 11, 2021.

2. Yáñez JA, Afshar Jahanshahi A, Alvarez-Risco A, Li J, Zhang SX. Anxiety, distress, and turnover intention of healthcare workers in Peru by their distance to the epicenter during the COVID-19 crisis. Am J Trop Med Hyg. 2020;103(4):1614-1620. doi:10.4269/ajtmh.200800

3. Zhang SX, Liu J, Afshar Jahanshahi A, et al. At the height of the storm: healthcare staff's health conditions and job satisfaction and their associated predictors during the epidemic peak of COVID-19. Brain Behav Immun. 2020;87:144-146. doi:10.1016/j.bbi.2020.05.010

4. Kang L, Ma S, Chen M, et al. Impact on mental health and perceptions of psychological care among medical and nursing staff in Wuhan during the 2019 novel coronavirus disease outbreak: a cross-sectional study. Brain Behav Immun. 2020;87:11-17. doi:10.1016/j. bbi.2020.03.028

5. Tan BYQ, Chew NWS, Lee GKH, et al. Psychological impact of the COVID-19 pandemic on health care workers in Singapore. Ann Intern Med. 2020;173(4):317-320. doi:10.7326/M20-1083

6. Zhang SX, Chen J, Afshar Jahanshahi A, et al. Succumbing to the COVID-19 pandemic-healthcare workers not satisfied and intend to leave their jobs. Int J Ment Health Addict. 2021;7:1-10. doi:10.1007/ s11469-020-00418-6

7. Ahlqvist V, Norrman A, Jahre M. Supply chain risk governance: towards a conceptual multi-level framework. Oper Supply Chain Manag. 2020;13(4):382-395. doi:10.31387/oscm0430278

8. Bliźniewska-Kowalska KM, Halaris A, Wang S, et al. A review of the global impact of the COVID-19 pandemic on public mental health, with a comparison between the USA, Australia, and Poland with Taiwan and Thailand. Med Sci Monit. 2021;27:e932220. doi:10.12659/MSM.932220
9. Brooks SK, Webster RK, Smith LE, et al. The psychological impact of quarantine and how to reduce it: rapid review of the evidence. Lancet. 2020;395(10227):912-920. doi:10.1016/S0140-6736(20) 30460-8

10. Hale T, Jessica A, Noam A, et al. Variation in government responses to COVID-19 Version 12.0. Blavatnik School of Government Working Paper; 2021. Available from: https://www.bsg.ox.ac.uk/ research/publications/variation-government-responses-covid-19. Accessed June 11, 2021.

11. International Risk Governance Council. Introduction to the IRGC risk governance framework, Revised version. Lausanne: EPFL International Risk Governance Center; 2017. doi:10.5075/epfl-irgc -233739 .

12. Roodenrijs JCM, Kraaij-Dirkzwager MM, van den Kerkhof JHTC, Runhaar HAC. Risk governance for infectious diseases: exploring the feasibility and added value of the IRGC-framework for Dutch infectious disease control. $J$ Risk Res. 2014;17(9):1161-1182. doi:10.1080/13669877.2013.875935

13. Schmidt K, Dressel KM, Niedrig M, Mertens M, Schüle SA, Groschup MH. Public health and vector-borne diseases- A new concept for risk governance. Zoonoses Public Health. 2013;60 (8):528-538. doi:10.1111/zph.12045

14. Collins A, Florin M, Renn O. COVID-19 risk governance: drivers, responses and lessons to be learned. J Risk Res. 2020;23(78):1073-1082. doi:10.1080/13669877.2020.1760332

15. International Risk Governance Council. Risk Governance: Towards an Integrative Approach. White Paper No. 1. Geneva: IRGC; 2005. Available from: https://www.springer.com/us/book/9781402067983\#. Accessed June 11, 2021.

16. Renn O. Risk Governance: Coping with Uncertainty in a Complex World. London: Earthscan; 2008. doi:10.4324/9781849772440

17. Joint Prevention and Control Mechanism of the State Council. Notice on furthering differentiated, region-specific and tiered prevention and control measures. (in Chinese, 2020); Available from: http://www. gov.cn/zhengce/2020-02/29/content_5485010.htm. Accessed June 11, 2021.

18. Joint Prevention and Control Mechanism of the State Council. Guidance on regular prevention and control of COVID-19. (in Chinese, 2020). Available from: http://www.gov.cn/xinwen/2020-05/ 08/content_5509965.htm. Accessed June 11, 2021.

19. National Health Commission of the People's Republic of China. Protocol for prevention and control of COVID (Edition 7). (in Chinese, 2020). Available from: http://www.gov.cn/xinwen/2020-09/ 15/content_5543680.htm. Accessed June 11, 2021.

20. Renn O, Walker K. Introduction. In: Renn O, Walker K, editors. Global Risk Governance: Concept and Practice Using the IRGC Framework. Dordrecht: Springer Netherlands; 2008:xxiii-xxviii. Available from: https://www.springer.com/us/book/9781402067983\#. Accessed September 20, 2021.

21. World Health Organization. Transmission of SARS-CoV-2: implications for infection prevention precautions. Available from: https:// apps.who.int/iris/handle/10665/333114. Accessed June 11, 2021.

22. Pang X, Ren L, Wu S, et al. Cold-chain food contamination as the possible origin of COVID-19 resurgence in Beijing. Natl Sci Rev. 2020;7(12):1861-1864. doi:10.1093/nsr/nwaa264

23. China National Radio. Expert comments on why China's covid vaccination puts the young before the old. (in Chinese, 2021). Available from: https://baijiahao.baidu.com/s? id= $1696246174866658368 \& w f r=$ spider\&for $=$ pc. Accessed June 11, 2021.

24. Jiang S, Zhang D, Irwin D. Semiformal organizations and control during the COVID-19 crisis in China. Asian J Criminol. 2021;16 (1):75-90. doi:10.1007/s11417-020-09334-z

25. Xu J, Cao B. Letter from China: managing the second-wave COVID-19 outbreak in Beijing. Respirology. 2021;26(3):275-276. doi:10.1111/resp. 14002 
26. Zhang X, Yang S. "A community system": a critical foundation for the epidemic prevention and control of SARS-CoV-2. Int $J$ Health Plann Manag. 2020;35(5):1246-1249. doi:10.1002/hpm.3005

27. The Guardian. China locks down part of Guangzhou amid outbreak of Indian COVID variant. Available from: https:/www.theguardian. com/world/2021/jun/01/china-locks-down-part-of-guangzhou-amidoutbreak-of-indian-covid-variant. Accessed June 11, 2021.

28. Rastogi S, Singh RH. COVID-19 pandemic resurgence: fixing the accountability for behavioral lapses. Ann Ayu Med. 2021; 10 (2):82-84. doi:10.5455/AAM.75790

29. Rastogi S, Singh RH. Taking lessons from the current pandemic to prepare for the future. Ann Ayu Med. 2020;9(3):144-147. doi:10.5455/AAM.1603468291

30. TheLancet. India's COVID-19 emergency. Lancet. 2021;397 (10286):1683. doi:10.1016/S0140-6736(21)01052-7
31. National Health Commission of the People's Republic of China Report on national covid vaccination shots. (in Chinese, 2021); March 4, 2021. Available from: http://www.nhc.gov.cn/xcs/yqjzqk/ 202104/2d30c4012929439c9e7cfff8415da13d.shtml. Accessed April $11,2021$.

32. China Youth Network. Interview of Zhang Wenhong: Chinese public's general reluctance to get vaccinated. (in Chinese, 2021). Available from: https://baijiahao.baidu.com/s?id=1696156858080213964\&wfr= spider\&for=pc. Accessed June 11, 2021.

33. National Health Commission of the People's Republic of China. Report on national Covid vaccination shots. (in Chinese, 2021); June 10, 2021. Available from: http:/www.nhc.gov.cn/xcs/yqjzqk/ 202106/99e9c0d61a244a49b74873c10da173df.shtml. Accessed June 11,2021
Risk Management and Healthcare Policy

\section{Publish your work in this journal}

Risk Management and Healthcare Policy is an international, peerreviewed, open access journal focusing on all aspects of public health, policy, and preventative measures to promote good health and improve morbidity and mortality in the population. The journal welcomes submitted papers covering original research, basic science, clinical \& epidemiological studies, reviews and evaluations,

\section{Dovepress}

guidelines, expert opinion and commentary, case reports and extended reports. The manuscript management system is completely online and includes a very quick and fair peer-review system, which is all easy to use. Visit http://www.dovepress.com/testimonials.php to read real quotes from published authors. 